\title{
East Asian economies and their philosophy behind success: Manifestation of social constructs in economic policies
}

\author{
Milan Lajčiak \\ Ambassador of the Slovak Republic to the Republic of Korea \\ Slovak Embassy in Seoul, South Korea \\ milan.lajciak@gmail.com
}

Abstract. The study contributes to broader conceptualization of East Asian Received: economies by elaboration of sociocultural and institutional approaches, explaining differences between Western and East Asian geography of thinking and focusing on the manifestations of Confucian values and their social constructs into organizational patterns of economic policies and business culture within East Asian economies. The analysis demonstrates that these factors has strongly impacted successful industrialization processes in East Asian countries and served as a strategic comparative advantage in their economic developmental endeavor. The paper is claiming that economic policies of the region would never be so effective if they would not be integrated into social organizational models of these countries. The ability of East Asian leaders to understand weaknesses and strengths of their societies in terms of market forces and to tap on their potential through economic policies was a kind of philosophy behind their success.

Keywords: East Asian economies, Confucianism, social constructs, organizational patterns, social manifestations in economic activities, role of leaders, mentality of labor force, economic policies

JEL Classification: A13, A14, N15

\section{INTRODUCTION}

In contemporary economy, creative innovation brought about by economic subjects and structures of domestic economy comes forward as one of its main priorities. Based on the innovative activity of economic agents and business enterprises, the synergy effect promoting transition for "the economy which is traditionally catching up" on an innovative trajectory of development can become a reality. 
There are diverse explanations for East Asian successful economic stories during their industrialization period. Political economy, market, cultural, institutional and international approaches have all contributed to that. They do not represent alternative concepts but rather complement each other and are used for different purposes.

The contribution of this study is to support broader conceptualization of East Asian industrialization success by elaborating on the "geography of thinking" and its manifestations in economic activities as a strategic comparative advantage of East Asian countries. The crucial moment is that economic actions are not asocial, not merely "economically rational" in an abstract, impersonal way. Economies are built by policies, but that are the people who craft them. East Asian economic stories show that their economic activities are not based only on the calculus of price and other rationality-determined pursuits. If one views these markets only through economic thoughts, one misses a set of social and political institutions that serve to integrate the economy. Complexity of East Asian economies requires additional explanation of their social construct, organizational patterns, thinking inclinations and working tenets as well as the role of leaders in both government and business, who, to a substantial degree, believed that their own success depended on economic achievements.

The lesson to be taken is that the strategy of comparative advantage in economic policies can be applied not only for industrial production strategy but also for distinctive social patterns that lend themselves to particular organizing strategies. East Asian economies have historically embedded value-based and traditionbased behavioral habits of generations that to a high degree entwined traditional practices with economic organization. They have organized their economic development in a way that has made sense to their people reflecting the local social context, draw their economic success on their own social and cultural repertoires, built on their own traditions and tapped on people's potential through integration of their policies into their system of values. People intuitively understood what was expected from them, even if they did not always like it. Based on these premises and in addition to acknowledgement of other schools of thoughts the paper contributes to cultural and institutional explanation of the East Asian economic phenomenon.

\section{EAST ASIAN SOCIETIES AND THEIR “GEOGRAPHY OF THINKING”}

To comprehend distinctive thinking patterns of East Asian societies one should understand Confucian culture that is a product of a long historical development. Confucianism is an ancient moral and ethical code of China that has spread through centuries across East Asian region. By the late nineteenth century, the whole East Asian region was thoroughly "Confucianized", that is, Confucian values and practices penetrated daily lives of people and the whole system of government were justified with reference to Confucian ideals (Bell, \& Chaibong, 2003). ${ }^{1}$

At the heart of Confucianism is the belief that social order depends on hierarchy, values and norms. The family is fundamental social unit and the roles of family members are arranged according hierarchical lines, each role with attendant duties and privileges. Likewise the society is ordered into distinct statuses, each with its own obligations and prerogatives. Confucian ethics dictates hierarchical relationships, requires subordination, identification with social roles and relies heavily on the self-control of individuals. Proper functioning of the Confucian "cosmos" depends on the loyal obedience of inferiors to superiors in the

1 Bell, D. A., \& Chaibong, H. (2003). Confucianism for the modern world. Cambridge University Press. ISBN: 978-0-521-52788-0 Paperback. 
social order and the carrying out of role-defined duties. Not individual freedoms but duties and social status affiliation is an imperative. This Confucian social arrangement has integrated human activities at all levels.

Conceptual differences in thinking patterns between East Asia and the West are found primarily in concepts of man - nature relationship and of man - man relationship. One can find variety of contradictory approaches within these two "relationship frameworks" between Confucian and Western cultures. Relevant topics for the study are of communitarian versus individualistic identity, social order versus social revolt, rule of law versus kinship relationship, obligations versus rights, pragmatism versus ontology as well as different perceptions of the role of trust, justice and harmony in the governing schemes of society (Lajciak, 2016). ${ }^{2}$ The scale of differences reflected in hierarchy of values, thinking preferences, behavioral patterns and organizational models are so big that in philosophical context one can label East Asians as Homo-EthicoPoliticus and Westerners with definition of Homo-Spiritus-Religiosus (Choi, 2015). ${ }^{3}$ These conceptual differences have engendered distinct manifestations in formation of East Asian modern markets, their business culture and in ways of conducting economic activities.

\section{2. "GEOGRAPHY OF THINKING" AND ITS MANIFESTATION IN EAST ASIAN ECONOMIES}

\subsection{East Asian market practices}

Neoclassical approach can sufficiently cover the functioning of western markets but have its limits in explaining some market practices of East Asian countries because of utility of settings where its institutional assumptions are in force. These assumptions institutionalize competitive "individualism" in numerous ways in its market structure and view economic action as a kind of "asocial" concept. Its economic model conceives actors as isolated units and considers a crucial condition to keep economic actors "apart". "Capitalists", in this model, ideally are independent and indifferent as to the parties from whom the buy or to whom they sell. Primary function of the state is to maintain competitive conditions between autonomous economic actors, both individuals and firms and to maintain open market.

Different story goes with East Asian countries that have distinct institutional assumption of market approach. Crucial economic actor in East Asian economies is typically not the "individual" but rather the "network" in which the individual is embedded. East Asian economies are rooted in institutions that encourage and maintain "ties" and are organized through networks of economic actors that are believed to be natural and appropriate to economic development. The "relationship model" of East Asian economies negates neoclassical assumption not only in perception of actors as isolated units but also in term of expectation that price is the critical factor in purchase decision. In East Asian "network economies" with value-based business culture the buyers in series of cases favor suppliers with whom they have established relations, rather than least-cost suppliers. This violates the principle of individualistic competitive approach due to the fact that the market is conditioned with different social construct and different value preferences. Neoclassical approach describes these practices as unfair and as market imperfections that distort their domestic economies. Criticism has been leveled mostly at the dense "networks of ties" between Asian companies that look in western eyes as cartels.

${ }^{2}$ Lajciak, M. (2016). East and West: Different Geography of Thinking and Implications on Actual Problems of Today's World. Moldavian Journal of International L aw and International Relations, 11(3).

3 Choi, Y.J. (2015). East and West: Man vs Spirit. Lexington, KY. 


\subsection{East Asian "network" economies}

Particular forms of economic "embeddedness" in the structure of social networks of each society have subscribed to different organizational designs of industrialization (Orru, Biggart, \& Hamilton, 1996). ${ }^{4}$ That is reflected in types of firms, their management and organizational strategies, giving every economy a distinctive character.

Japanese economy is dominated by keiretsu, descendants of pre-World War II family based business conglomerates zaibatsu which organized their business through their own financing system. Inheritance practices in Japan are based on "primogeniture", that means the entire inheritance goes to the oldest son. This practice allowed merchant family's fortunes to remain intact under stewardship of the heir. Successful families thus had huge sums of money available to finance the business of affiliated branches under the "badge" of the "mother house". In a post-war period keiretsu, though no more family businesses but rather networks of companies with interlocking shareholding businesses, based on communitarian logic, continued to rely on their own finance sources. The important point is that banks are encapsulated within business networks and functioned as direct financing houses to keiretsu. These market networks constitute a kind of "intercorporate alliances" or "alliance capitalism" (Gerlach, 1992). ${ }^{5}$ Many large companies are members of these networks (Mitsubishi, Mitsui, Sumitomo, Fuji etc.). In addition to keiretsu there are also other linking forms of Japanese businesses, for example an affiliation of a major manufacturer with its subcontractors (Toyota "independent group") or common investments of small neighborhood retailors.

South Korean economy resembles on the surface Japan's market networks, but in terms of decisionmaking processes has some substantial differences. South Korean economy is dominated by chaebols, networks of conglomerates owned and controlled by single persons or families and organized vertically through "central staff", which may be holding companies or mother firms. In difference to communitarian logic of Japanese businesses, Korean chaebols have patrimonial logic of business structure, where all powers belong only to the leader of chaebol. Patrimonialism has deep historic roots in South Korea and on the related logic of vertical hierarchical arrangements are organized various types of social relations as well. Companies such as Samsung, Hyundai Motor, SK, Lucky-Goldstar represent major chaebolnetworks that control around 90\% of economic activities of top thirty chaebol conglomerates (Kato, 2014). ${ }^{6}$

Taiwan network economy is ruled by family firms and family owned conglomerates, which are called jituanqiye (entrepreneurial integrity groups). Taiwanese business structure is based on patrilineal logic. In difference to Japanese and Korean economies ruled by networks of medium sized to very large firms, Taiwanese networks link less numbers of smaller firms and occupy less central position than keiretsu or chaebols. They often cross-invest in businesses, hold multiple positions throughout the network and act as suppliers or upstream producers to downstream firms. Chinese societies practice "partible inheritance" that means the division of a family estate equally among all sons. As a result, families divide their fortunes every generation which does not allow accumulation of large sums of money. Instead, there is a great pressure within families to develop multiple businesses so that at the death of the family head each son can claim an independent enterprise. Strong social norms dictate that family members or close friends assist financially each other and system functions as alternative institutional finance arrangements. Due to this system there

\footnotetext{
${ }_{4}^{4}$ Orru, M., Biggart, N. W., \& Hamilton, G. (1996). The economic organization of East Asian capitalism. Sage Publications. ISBN: 0-76190480-8 (pbk: Alk. Paper)

${ }^{5}$ Gerlach, M. L. (1992). Alliance capitalism: The social organization of Japanese business. Univ of California Press. ISBN 0-520-07688-5 (alk. Paper), ISBN 0-520-08607 (pbk.: alk. paper)

${ }^{6}$ Kato, K. (2014). Top four chaebol generate $90 \%$ of South Korean conglomerate profits. Nikkei Asian Review.
} 
is relatively weak formal banking system in Taiwan. Ironically, strong family system produced the strength of Japanese banks.

Japan, South Korea and Taiwan economies demonstrate diversity of institutionalized business networks and differing logics behind their structures but all of them are based on network relationships. Japanese firms enact communitarian logic, Korean firms represent patrimonial logic and Taiwanese firms reflect patrilineal logic. This has important implications for the ways of labor organizations, character of subcontracting relations between firms, investment patterns and other business activities. Each of networking logic is a manifestation of common cultural basis and of Confucian patterns of interaction, through which prevailing majority of socio-economic spheres of life have been organized.

Some parallels of East Asian organizational socio-economic patterns can be found also with certain Western economies. In Japan and Germany the legacy of feudalism led in modern times to strong elite classes and solid alliances between private business and the state that have maximized utility of public and private institutions. In Taiwan and Italy, where the state is much weaker and family structures are stronger, modern economic organizations cooperate on horizontal networks with strong cooperative traits at the level of small and medium businesses. In South Korea and France the historical tradition of a strong central state and fragmented regional elites has led to the "dirigiste role" of the central government in shaping their economic and industrial structure (Orru, Biggart, \& Hamilton, 1996)7.

\subsection{Governance environment in East Asia}

Economic activities do not operate in a vacuum, they are rather shaped by the governance environment of every society that has enormous impact on the way of doing business.

Governance style in East Asian economies during industrialization period was very different from Western practices and can be depicted as "relation-based" versus "rule-based" systems (Li, 2009). 8

Western societies tend to follow public rules, such as law government regulations and public information. They rely on formal contracts, legal courts, lawyers and accountants to carry out transactions and protect their interest. One can call it "rule-based governance". Confucian societies in difference to the West relied still in recent past on personal relations to conduct business. Contracts were secured more through gentleman agreements than through written paper, disputes were settled privately, public information was not regarded as trustworthy as personal contact. This is called "relation-based governance". Rule-based communication and agreements are explicit and formal, they can be verified by third parties, documents and procedures are standardized. Relation-based communication and agreements are informal and implicit, yet each party perfectly understands what it entails. It is difficult to be verified by third party and can't be enforced in a court of law.

Rule-based and relation-based governance represent two types of governance environment that involve different social and business costs. For rule-based governance to work effectively, society must make investments to establish a large complex political and legal infrastructure. Once established, whether this infrastructure is used in one or million cases the costs will always remain approximately the same. In economic terms, rule-based system has high fixed costs but decreasing incremental costs. In contrast,

7 Orru, M., Biggart, N. W., \& Hamilton, G. (1996). The economic organization of East Asian capitalism. Sage Publications. Page 382. ISBN: 0-7619-0479-4 (alk. Paper), ISBN: 0-7619-0480-8 (pbk: Alk. Paper)

${ }^{8}$ Li, S. (2009). Managing international business in relation-based versus rule-based countries. Business Expert Press. ISBN-13: 978-1-60649084-6 (pbk) 
relation-based governance involves low fixed costs, requires a minimal legal infrastructure but has rising incremental costs. The parties of relation-based governance are able temporarily to avoid the large upfront investment costs connected with establishing a complete legal infrastructure because rely for protection on their private connections, not the public legal system.

Low fixed costs of relation-based governance system of East Asian countries was one of elements that contributed to their economic success though the system was non-transparent, flawed and with a lot of room for corruption.

Dynamics of growing business and cultivation of business relationships with outside world through global networking impacted East Asian relationship-based economies. This process imperatively moved them to embrace more rules into the governance and gradually transformed them into various stages of rule-based economies. However, old traditions have remained still deeply vested in East Asian societies until todays and relation-based systems work in parallel as the "shadow eminence factor" in their business culture.

\section{AUTHORITARIAN RULERS, BUSINESSMEN AND LABOR FORCE IN EAST} ASIA

\subsection{Authoritarian rulers and business leaders}

The history has shown that from 1970s to 1990s highly authoritarian governments in some East Asian countries such as South Korea, China, Taiwan, Singapore but also Malaysia and Indonesia did a better job at alleviating poverty than democracies in India and the Philippines. This issue has contributed to one of the most controversial themes - if rapid economic success of emerging markets would be possible without authoritarian rule.

Pro-authoritarian thinking argues that in developmental phase of industrialization, authoritarian governments insulate technocrats from the potential pressures imposed by politicians, civic groups and business interests, allowing them to implement long term growth strategies without worrying about shortterm political repercussions. Apology goes further arguing that authoritarian governments also permit fast decisions while democracies, on the other hand, are too fractured, its politicians too susceptible to the concerns of their electors to pursue consistent policy needed to achieve rapid economic growth (Schuman, 2009). ${ }^{9}$ The truth is that authoritarian regimes differed from case to case, some of them were business oriented and less corrupted, others were interested only in cementing their powers in Machiavelli way. Their role should not be generalized and their controversy should be viewed through eyes of short and long term perspectives and through the balancing judgments of their contribution to economic achievements as well as of their records of human rights crimes. Authoritarian regimes of East Asian countries on one side depressed civil liberties among their people and on the other side, ironically, by accelerating economic development, contributed in the end to processes that gradually brought democratization. They will be remembered as economic facilitators as well as dictators.

Authoritarian leaders of successful East Asian economies, such as Lee Kuan Yew of Singapore, Park Chung-hee of South Korea and Chiang Kai-schek of Taiwan faced remarkably similar economic and political conditions. None of them was economists by nature or by experience. They were guided not by

${ }_{9}^{9}$ Schuman, M. (2009). The miracle: the epic story of Asia's quest for wealth. Harper Collins. ISBN: 978-0-06-134669-9 
ideology or textbooks but by simple pragmatism, were less ideological than many other leaders of developing nations and more open to adapting policies to the needs of their economies. Instead of theories they followed their instinct, their mindset was oriented with what is useful to make things working. They implemented policies that were integrated into traditional social construct and effectively tapping on the labor potential of masses. This is not to say that they were hero. They suppressed democracy and human rights and used drastic measures to cement their rule, some of them been guilty of corruption on massive scale. Though it is impossible to justify their actions, it is equally impossible to deny the economic results they achieved.

In addition to the controversial role of authoritarian regimes during industrialization process of East Asian economies it is important not to omit the role of business leaders. East Asian region since 1950s has been blessed by several devoted, determined and inventive businessmen who to a substantial degree believed their own success depended on economic achievement of the country. Their strong vision, creativity and ability to compete in international markets were crucial to East Asian economic success. Electronic genius Akio Morita and auto innovator Soichiro Honda of Japan, Hong Kong plastic maker Li Kaoshing, industrialist Chung Ju Yung of South Korea, computer entrepreneurs Stan Shih of Taiwan but also Liu Chuanzhi of China, they have forever altered the global marketplace by building companies of international stature against odds.

\subsection{Mentality of labor force "to follow"}

No amount of leadership and no management technique will succeed if people would not follow or refuse to be organized. East Asians have been successful because they were hungry for success, patient and worked hard for small gains. They exhibited certain behavior patterns based on Confucian values that substantially contributed to their economic success. Among its main tenets was the stress on societal order, respect for hierarchy, self-discipline, bureaucratic excellence, devotion to a strong work ethic and to education, all elements that together with the propensity to save rather than spend (accumulation of capital for industrial investments) laid the groundwork for economic development. Success of East Asian economies rode on the backs of people with their ability to mobilize themselves behind their leaders, both at government and business levels, as well as their desires to improve themselves and to raise standards of their entire societies. The most striking in this context was mobilization of labor force through a "big push" policy of South Korean President Park Chung-hee who was harnessing on Confucian discipline and state nationalism and calls upon the people to behave as industrial soldiers (saneop jeonsadeul) (Tudor, 2012) ${ }^{10}$ to achieve economic goals.

East Asian economies generally after World War II suffered of capable and skilled small and medium enterprises. To the difference of western societies with relatively developed middle class actively picking business opportunities, East Asian economics had to resort in addition to incentives also to "pushing" methods. This theorem can't be applied with the same force to all East Asian countries. South Korea and Singapore were on a weaker side of this model and what was possible to achieve through incentives in Taiwan, Hong Kong and Japan, was needed to be done in these two countries through instructions and control. Especially in case of South Korea this kind of mobilization did more to create South Korean industry than other initiatives.

10 Tudor, D. (2012). Korea: The impossible country. Tuttle Publishing. ISBN: 978-0-8048-4252-5 
The role of middle class in economic activities was recently demonstrated in transformation efforts of central European countries from communism and planned economy to democracy and market economy. This social class represented in market forces by small and medium enterprises appeared to be a major driving force behind their successful transformation process after collapse of communism. The maturity of this socio-economic echelon and its derivative civic society works as the source of intermediating institutions that bridge the elite and the masses of society. Functional equivalent of Western civil society in East Asian Confucian societies was, to some extent, the set of stable, prosperous families, together with their supporting relationship groups (clan associations, guilds, hospital committees etc.). These groups served as a kind of an institutional civic structure of East Asian societies providing people with socio-economic security and fostering the trust. The missing "maturity" of small and medium enterprises as representatives of western middle class in terms of entrepreneurial skills, experience and active business attitudes was compensated in East Asian economies by Confucian ethic, discipline and hierarchical order and in case of South Korea by "pushing" methods in achieving economic goals.

\section{COMMONALITIES AND DIFFERENCES OF EAST ASIAN ECONOMIC POLICIES}

There are common approaches as well as substantial differences in economic policies of East Asian countries. Disparities are apparent at least in the role of government and in the role of foreign investments in industrialization efforts.

Japan and South Korea with strong nationalistic policies focused on building their industries on their own national private companies, "picking winners" and supporting them. Singapore did not believe in its own capacity of building industry and, defying the "developmental" logic of that time, focused on creating business-oriented environment for attracting foreign investments. Hong Kong did not conduct Asian way of "command" policies of government into the business, didn't "pick winners" as in Japan or South Korea and contributed into its success through smart policymaking and creation of business-oriented conditions. Taiwan technocrats assisted remarkably in targeted assistance to advance Taiwan electronic sector but that was mostly the privat sector efforts that brought sustained growth.

East Asian "early movers" (Japan, South Korea, Hong Kong, Taiwan, Singapore) all lacked natural resources and had to import raw materials including crude oil to survive. All of them except Japan had poor small population unable to support industry on their own. These factors forced them to turn to the international economy. They linked their economies to the global marketplace more tightly than other emerging nations. They opted for "export-led" growth strategy that was perhaps the most important single element of their policies of rapid growth. Though it sounds like common sense today, the export route was not seen that way in the 1950s and 1960s. This policy was considered heretical in development circles because development specialists advocated restricted trade and restricted foreign investment, pursuing "import substitution" to disengage from a world economy and to avoid dependency on former colonial masters. These ideas took hold in large parts of Latin America and Africa. Moreover the emergence of Soviet Union as a superpower after World War II was providing a non-capitalist alternative to development. East Asian choice to hitch onto the forces of globalization and ignore the prevailing economic wisdom is 
one of key policies that helped to bring "miracle" to happen.. As Paul Krugman wrote, "the global economy was not, as so many "dependency" theorists had claimed, rigged against latecomers" (Krugman, 1999).11

Once the key policies were set in place by the "early movers", they were spread across Asia. The process started with Japan that provided a kind of "roadmap" to development which many East Asian countries followed in some form. Even Deng Xiaoping in China and Mahathir Mohamad in Malaysia were influenced by these policies.

\subsection{Japan}

Japan's development system took shape in mid-1950s and was based on heavy role of state in industrialization process (later known as Asian model). Ministry of Industry and Trade (MITI) served as "command central" of economy with tremendous formal authority. Japan's economic policy was devised and implemented primarily by career bureaucrats, unlike in USA, where elected leaders have greater influence. To create new comparative advantage Japan pushed economy into heavy industry through state intervention and ensuring necessary financial resources ("industrial policy"). Similarly as in USA in late 18 th century when A. Hamilton was promoting the need for extraordinary aid and for protection to industries vital to US national interests to ensure their ability to compete more advanced economies of Europe (Chernow, 2004), ${ }^{12}$ Japan picked "winners" by targeting certain industries with growth potential that could become globally competitive. The early "winners" were large business groups called keiretsu, responsible for bringing MITI industrial policy to life, globally recognized as Mitsubishi, Sumitomo, Fuji, Mitsui etc. They had each a bank and trading firm at its core with several industrial firms attached around them linked through cross-shareholdings. MITI lost some legal powers in 1960s but maintained further levers of control in economy through "administrative guidance" (command of finance).

Secret of Japanese "model" was linkage of state intervention to market forces that was different from majority of emerging world. Acceptance of global markets influence into development strategy was an element that other state-led economies often ignored. Its project from the start was oriented for making Japan globally competitive. Export was considered as a lifeline for Japan and that is why industrial policy was intimately linked to the demands of international trade. Free competition was considered by Japanese as the best measure to exploit human creativity. Japan was creating homegrown industries and carefully restricting foreign investment inflow considering it can stifle advancement of Japanese business. While MITI was playing key role in Japanese economic success, one should not downplay the role of entrepreneurs, corporate micromanagement, small firms and households at the grassroots level, their prompt response to market conditions and Japanese workers attitude that were equally important. Scale of contribution of Japanese corporates into Japanese economic success is documented by stories of some most successful industries (motorcycles, robotics, consumer electronics) that prospered without significant assistance from MITI. "Sony" belongs to these stories as well. Japan nationalism and communitarian logic made Japanese economic policies functioning as a monolithic entity in which government, business and banks acted as coordinated departments of corporation "Japan Inc.".

${ }^{11}$ Krugman, P. (1999). Why Adam Smith Would Love Asia. Time (Asia edition), August 23-30, 1999.

12 Chernow, R. (2004). Alexander Hamilton. Penguin Books, New York. ISBN: 1-59420-009-2 


\subsection{South Korea}

President Park Chung-hee (1961 - 1979) who led South Korea for 18 years was a dictator. He left dual legacy - astounding economic success and political repression. He believed that the democratic experiment in Korea in 1950s unlike political systems of the West didn't emerge naturally from the course of societal development. He was convinced that it was imposed from outside and that impoverished pre-modern Koreans were not able to enjoy fruits of that system. In his eyes political freedom meant nothing without economic growth and Korea needed to develop a strong economy before democracy.

Park's obsession with economic development was driven among others also by his security concerns that only industrialized state is a strong state, capable of building weaponry army. He believed that economic development can't be entrusted to the private sector alone (not enough skills and resources to build strong economy) and should be aided by state. Korea emulated Japan model of capitalism - picking up "winners" and supporting them by financing. No nation has profited more from understanding Japanese success than South Korea. Park brought Japanese model to much higher level of centralization and state control. His method was "Big Push" policy and he behaved like frontline commander, monitoring progress of every single project and being obsessed by keeping deadlines and quality. Park forged relationships with a handful of business leaders who implemented the industrial plan in selected industries. Similarly as Japan he picked "winners" and nurtured the massive conglomerates that came to dominate the economy - chaebols. These family business groups resembled Japanese keiretsu and became engines for Korea's growth (Samsung, Hyundai, LG and others). While protected at home they were forced, similarly as keiretsu in Japan, to compete internationally against more advanced global companies from the early stage. Following Japanese way President Park combine state-led economy with global market. The system was far from perfect but was able to force chaebols to strive to excel. This was one of key factors in Korea's development story. In only thirty years South Koreans transformed a nation poorer than Liberia or Zimbabwe into a member of the rich countries club (OECD).

\subsection{Singapore}

The constant factor throughout Singapore's entire story was the combative and highly pragmatic Prime Minister Lee Kuan Yew who led Singapore over 30 years (1959 - 1990). Singapore adopted some aspects of the developmental model, as practiced in Japan and South Korea, primarily a heavy role of the state in the economy but Singapore's version had some crucial differences. The most important deviation from Japanese and Korean policies was the use of foreign investment to generate rapid growth. Singapore replaced business activities of chaebols in South Korea or keiretsu in Japan with foreign multinational corporations and linked Singapore's future to the forces of globalization to much greater degree. His strategy was based on interplay of government intervention with integration into global economy while strongly supporting the flow of foreign capital into the country. This approach differed Lee from Japan and South Korean leaders, whose priority was to create world-class corporations of their own. Lee did not trust domestic market forces to develop Singapore quickly enough by domestic companies. He believed the state has to intervene in economic development. Lee turned the government into a foreign investment promotion machine and bolstered the confidence of foreign investors, something that would xenophobic South Korean nationalist Park Chung-hee never allowed. This kind of thinking was at that time radical because many development economists and leaders of postcolonial era considered multinational corporations, especially American ones, as bearers of neocolonialism, exploiting resources and labor of poor nations. The crucial factor behind Lee's success was the foreign investments pouring into the country. The starting point of 
Singapore was simple guiding principle for survival - to be better organized and more efficient than others in the region to attract foreign investments. This was also one of reasons why Lee focused on building "environment of meritocracy" - system in which the more people educate and train themselves, develop skills and contribute on the economy, the more are rewarded. As a result, Singapore was able to compress the development pattern of Japan and South Korea into more capital intensive and high skill industries.

Lee Kuan Yew was a proponent of Asian values behind East Asian economic success. Lee argued that culture and economic success are linked. If there is no culture that place value in learning and hard work and deferment of present enjoyment of future gain (Confucian values) the progress is much slower. Lee dismissed fundamental tenets of Western democracy arguing that the assumption that all men are equal and capable of equal contribution to the common good is flawed. Main objective of Eastern societies in Lee consideration is to have a well-ordered society. Rule of law and not democracy is what East Asians need, not individual freedoms.

\subsection{Hong Kong}

The history of Hong Kong economic miracle raises questions about the validity of the so called Asian model of development (state-led industrialization). Proponents of this model believe that state-led policy accelerated not just the growth of many Asian economies but also contributed to a shift in their structure to high value-added and more technologically intensive industries (Schuman, 2009)13 and that this would never happen so quickly in a purely free market system without state intervention. Contrary to this belief the case of Hong Kong showed that it could be possible.

Hong Kong became East Asian "tiger" not due to the government intervention but because of free markets, free trade and forces of globalization. Hong Kong's British governor and his small team contributed to the development not through command policies and state control but through smart policymaking, creating stable, efficient, open and corruption-free economic environment, similar to Singapore, that attracted businessmen to build their companies in Hong Kong. Hong Kong's economic profile was based on many small industrialists backed by strong finance and trading firms, very different from Japanese and South Korean policies that were working on changing the nature of their economies by building heavy and high tech industries. Li Ka-shing was one of those entrepreneurs who capitalized on Hong Kong's liberal economic regime and sparked Hong Kong's miracle.

\subsection{Taiwan}

Taiwan followed the concept of interventionist state. Though Taiwan's technocrats did not adopt Japan and Korean style of state-led industrialization wholesale, they played much more instrumental role in guiding economic development than British servants in Hong Kong.

Taiwan and Hong Kong economies are in many ways similar - both were composed of large number of small firms, heavily dependent on exports, got much of their business through outsourcing from foreign firms and developed strong consumer electronics industries at approximately the same time. One of key differences between Taiwan and Hong Kong was a government policy. Taiwan government heavily assisted for the advancement of its electronic sector and developing technology industries while Hong Kong civil servants implemented generally pro-business policy without targeting specific industries. Taiwan decided to 
build its economy on high technologies that considered as the best way of continued prosperity. Over the years Taiwan took over Hong Kong and its companies advanced faster into higher level of technologies because were better skilled at product design and R\&D. Hong Kong electronic companies remained mostly in their original business model, more low-cost labor oriented and focused rather on manufacturing flexibility than on high levels of technological capabilities.

\section{BREAKING THE MIDDLE INCOME "ENTRAPMENT"}

There are several cases of remarkable economic developments and fast industrializing "latecomers" after World War II but only some of them were able to escape middle income entrapment. East Asian economies have shown the way that it is possible.

There are several factors that assisted East Asian economies to be successful in breaking this "pitfall". Economic model of "picking winners" and supporting them with financing and protective barriers worked in Japan and South Korea. "Winners" grew up in business networking and achieved capital investment to the extent they could build their own capabilities for technological innovations. This was an important startup position for strategic coupling into global business networks. Export oriented policy of all East Asian economies compelled East Asian region to focus on higher technological standards that helped them to "catch up" with technological challenges and modernization of the West. Global exposure was a major factor in opening doors to higher technologies. Foreign investments flow into the region, mostly to Singapore, Hong Kong and Taiwan played another facilitating role. Over the decades American firms have made their products in more and more advanced industries by East Asian manufacturers including computers and high tech electronics. The main reason for this shift was labor cost, stable economic environment, pro-business regulatory schemes and investment climate welcoming foreign businessmen more than elsewhere in developing world. Manufacturing industries did not shift to Africa, Middle East or Latin America in such a degree as to East Asia. Enthusiasm for education based on Confucian values was giving a big push in sending students abroad to renowned universities and in building quality education system at home. Highly educated human potential brought East Asian capabilities to manage higher technologies and to progress on their own innovations as a prerequisite to breaking middle income entrapment.

As it has been proved through many economies, adaptation of technology is not independent of human skills and capacities. One can import technologies from other countries but the success in large part depends upon how well they blend into the organizational structure of the host society, what managerial capacities the country possess and what is the human potential to utilize, maintain and innovate. Confucian values of East Asian societies with strong emphasis on education and with policies of global exposure paid off in terms of managing high technologies and getting to the line of higher added value industries.

\section{CONCLUSION}

Economic organizations do not develop independently of the rest of society, rather, they are embedded in, and grow out of, the social, political and institutional forces that are in place in each society. There are various organizational patterns that have emerged throughout the modern market economies. They are shaped by each country's history, political economy, cultural traits, and social structural conditions.

East Asian countries have developed distinctive geography of thinking, behavioral patterns and social construct that have manifested into specific organizational modes of their economies. Some technical requisites that are considered in Western minds crucial for successful western markets are frequently not in 
evidence in Asia. East Asian markets espouse different institutional logics from those of Western economies. Their logic is rooted in connectedness, relationship lines and networks and they believe that, in difference to Western economies that maintain autonomy among actors, social relations among economic actors do not impede market functioning, but rather promote it. Business relationships in East Asian economies are manifested in multiple ways at interpersonal level but they are seen dramatically and most importantly in business networks. Every East Asian country has different logic behind the structure of these networks that gives each one the distinctive character.

Broader conceptualization of East Asian economies show that "secret" behind the East Asian economic success is not merely the issue of economic policies per se. The truth is that East Asian growth was generated through competent execution of appropriate policies with central role of government in prevailing majority of economics but the key point behind their success is the matter of effectiveness of economic policies and philosophy behind this phenomenon is an integration of these policies into social patterns and behavioral modes that served as a strategic comparative advantage of East Asian economies.

\section{REFERENCES}

Bell, D. A., \& Chaibong, H. (2003). Confucianism for the modern world. Cambridge University Press.

Buchanan, J. M., \& Tullock, G. (1962). The calculus of consent (Vol. 3). Ann Arbor: University of Michigan Press.

Chen, S., \& Ravallion, M. (2008). The developing world is poorer than we thought, but no less successful in the fight against poverty.

Chernow, R. (2004). Alexander Hamilton. Penguin Books, New York. ISBN: 1-59420-009-2.

Choi, Y.J. (2015). East and West: Man vs Spirit. Lexington, KY.

Gerlach, M. L. (1992). Alliance capitalism: The social organization of Japanese business. Univ of California Press.

Kato, K. (2014). Top four chaebol generate $90 \%$ of South Korean conglomerate profits. Nikekei Asian Review.

Krugman, P. (1999). Why Adam Smith Would Love Asia. Time (Asia edition), August 23-30, 1999.

Lajciak, M. (2016). East and West: Different Geography of Thinking and Implications on Actual Problems of Today's World. Moldavian Journal of International Law and International Relations, 11(3).

Li, S. (2009). Managing international business in relation-based versus rule-based countries. Business Expert Press. ISBN-13: 9781-60649-084-6 (pbk).

Neville, R. C. (2000). Boston Confucianism: Portable tradition in the late-modern world. SUNY Press. ISBN: 0-7914-4717-0 (al. paper).

Ng, T. P. (2007). Chinese Culture, Western Culture: Why Must We Learn from Each Other?. iUniverse.

Orru, M., Biggart, N. W., \& Hamilton, G. (1996). The economic organization of East Asian capitalism. Sage Publications.

Schuman, M. (2009). The miracle: the epic story of Asia's quest for wealth. Harper Collins. ISBN: 978-0-06-134669-9.

Shaomin, Li (2015). "Together of Separate Checks?": Why the East and West conduct business in different ways. Center for Modern China Foundation. ISBN-13: 978-1511951333

Tu, W., Hejtmanek, M., \& Wachman, A. (Eds.). (1992). The Confucian world observed: A contemporary discussion of Confucian bumanism in East Asia. University of Hawaii Press.

Tudor, D. (2012). Korea: The impossible country. Tuttle Publishing. ISBN: 978-0-8048-4252-5.

Wan Jr, H. Y. (2011). Economic Development in a Globalized Environment: East Asian Evidences. Springer Science \& Business Media. ISBN: 0-387-24205-8.

Weber, M. (1992). The Protestant ethic and the" spirit" of capitalism and other writings. 2nd Edition. Published by Routledge. ISBN: 978-0-415-25406-9 (pbk).

Weber, M. (2009). The theory of social and economic organization. Simon and Schuster.

Wei-Ming, T. (2008). The rise of industrial East Asia: The role of Confucian values. The Copenhagen Journal of Asian Studies, 4(1), 81.

Wei-ming, Tu. (1996). Confucian traditions in East Asian modernity: Moral education and economic culture in Japan and the four mini-dragons. Harvard University Press. ISBN: 0-674-16087-8.

Yew, L. K. (2013). The Grand Master's insights on China, the United States, and the world. ISBN: 978-0-262-01912-5. 